\title{
Radioactive Aerosols Monitoring of the Surface Air near the Shelter Object within 1998-2019
}

\section{Ключові слова:}

monitoring of radioactive aerosols, long-lived nuclides, volumetric activity, New Safe Confinement.

\begin{abstract}
The results of long-term monitoring (1998-2019) of radioactive aerosols (RA) in the surface air near the Shelter object (SO) during works on projects implementation on creation of the New Safe Confinement's "Arch" (NSC) are presented. The composition of long-lived nuclides (LLN) in RA using for assessing the personnel radiation safety are included the following nuclides: $\Sigma \alpha$-LLN $\left({ }^{238,239,}{ }^{240} \mathrm{Pu},{ }^{241} \mathrm{Am}\right)$ and $\Sigma \beta$-LLN $\left({ }^{137} \mathrm{Cs},{ }^{90} \mathrm{Sr}+{ }^{90} \mathrm{Y},{ }^{241} \mathrm{Pu}\right)$. The average activity of $\Sigma$-LLN was about $17 \mathrm{mBq} / \mathrm{m}^{3}$ in the end of 1990th in the air near the SO. It was shown that the main decline of aerosol situation near the SO, when RA volumetric activity increased ten-fold as compared to the beginning of 2000s, was due to radioactive dust resuspension during technological works. First, during earthwork at building of foundation strips of the NSC in 2010. During this period, average annual volumetric activity of $\Sigma$-LLN was $80 \mathrm{mBq} / \mathrm{m}^{3}$, and weekly maximum activity rose to $6 \mathrm{mBq} / \mathrm{m}^{3}$ for $\Sigma \alpha-L L N$ and for $\Sigma \beta$ $\mathrm{LLN}$ to $520 \mathrm{mBq} / \mathrm{m}^{3}$. Second, when dismantling concrete and metal structures of the Shelter object in 2016, average annual activity of $\Sigma$-LLN was $62 \mathrm{mBq} / \mathrm{m}^{3}$, and weekly maximum activity reached $\Sigma \alpha$-LLN $-18 \mathrm{mBq} / \mathrm{m}^{3}$ and $\Sigma \beta$-LLN $-1,400 \mathrm{mBq} / \mathrm{m}^{3}$. After the NSC commissioning the $\Sigma$-LLN volumetric activity in the air dropped to $0.8 \mathrm{mBq} / \mathrm{m}^{3}$ in 2019 . It is shown that after 2010 in the RA of the surface air there is an increase in the activity of ${ }^{137} \mathrm{Cs}$, not associated with fuel particles, the average relative share of which in the beginning of 2000 s was about $20 \%$, in 2013 reached to $62 \%$, and after 2017 was in the range of $50-55 \%$.
\end{abstract}

\section{Introduction}

The accident occurred at the Chornobyl NPP (ChNPP) in 1986 was the worst in nuclear power engineering and a turning point in an improvement of ecological safety of nuclear cycle facilities. The Shelter object (SO) was built in 1986 over the destroyed power $4^{\text {th }}$ Unit of the ChNPP, which did not become reliable and secure place for huge amount of fuel containing materials (FCM) located inside it. The natural factors made impact on FCM and promoted to its degradation and production of the radioactive dust with potential capability to resuspension. Radioactive releases from the SO were spreading in close area and contaminating environment around.
It was a reason for the RA monitoring in the ground level air around the SO to obtain an information on nuclides content in the aerosol, their activity and ratio nuclides.

The monitoring results are serving for an adequate estimation of the radiation safety of personnel and impact for the environment.

\section{Materials and methods}

Layout of aerosol sampling facilities within the SO local area. The local area is enclosed territory around the SO, where the staff should use respiratory protective equipment. Radioactive aerosols in the surface air were sampled by three aspiration units, which were placed

(C) O. K. Kalynovskyi, V. O. Krasnov, O. V. Filippov, 2021 
along the local area periphery (see Fig. 1). The aerosols were precipitated on FPP-15-1,5 filters. A filtration air rate was within $500-600 \mathrm{~m}^{3} /$ hours. Usually sampling period was in the range from 10 to 17 days.

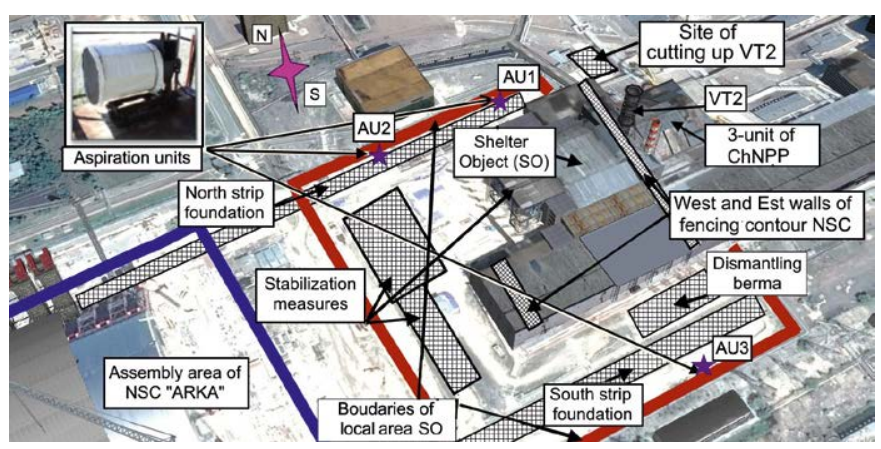

Fig. 1. Scheme of layout in the local area of RA sampling points and work realization places during the NSC "Arch" construction

Gamma-spectrometry determination of content and activity of nuclides in aerosols. One of the criteria for assessing the radiation safety of personnel carrying out works in the local area is the volumetric activity (VA) of long-lived nuclides (LLN) in the surface air around the SO. The content of monitored radionuclides, whose contribution in activity of LLN is more than $2 \%$, from the beginning of 2000 s to the present is almost unchanged and includes: $\Sigma \alpha$ - LLN ${ }^{238+239+240} \mathrm{Pu}$ and ${ }^{241} \mathrm{Am}$ and $\Sigma \beta$-LLN $-{ }^{137} \mathrm{Cs},{ }^{90} \mathrm{Sr}+{ }^{90} \mathrm{Y}$ and ${ }^{241} \mathrm{Pu}$ (Table 1).

Table 1. Relative share

of controllable radionuclides in LLN, \%

\begin{tabular}{|c|c|c|c|c|c|c|c|c|}
\hline \multirow{2}{*}{ Year } & \multicolumn{3}{|c|}{$\Sigma \beta$-LLN } & \multicolumn{5}{c|}{$\sum \boldsymbol{\alpha}$ - LLN } \\
\cline { 2 - 9 } & ${ }^{137} \mathrm{Cs}$ & ${ }^{90} \mathrm{Sr}+{ }^{90} \mathrm{Y}$ & ${ }^{241} \mathrm{Pu}$ & ${ }^{241} \mathrm{Am}$ & ${ }^{238} \mathrm{Pu}$ & ${ }^{239} \mathrm{Pu}$ & ${ }^{240} \mathrm{Pu}$ & other \\
\hline 2001 & 31 & 53 & 15 & 46 & 17 & 13 & 21 & 3 \\
\hline 2015 & 33 & 56 & 11 & 56 & 13 & 11 & 18,4 & 1,6 \\
\hline 2020 & 34 & 56 & 9,8 & 57,8 & 12 & 11 & 18 & 1,2 \\
\hline 2025 & 34 & 57 & 8,8 & 59 & 11 & 11 & 18 & 1,1 \\
\hline
\end{tabular}

Determination of radionuclide content in aerosols was carried out using $\gamma$-spectrometry with high-definition semiconductor detector and analysis spectrums by program Genie 2000 (Canberra). The contribution dynamics of the $\gamma$-activity of detected nuclides to a total $\gamma$-activity of RA is shown in Fig. 2. The share of ${ }^{137} \mathrm{Cs}$ activity in the total $\gamma$-activity in 1990 was about $47 \%$. It reached a maximum $(97 \%)$ in 2005 , and then began to fall. The share of ${ }^{241} \mathrm{Am}$ increases every 5 years from 2000 by about $0.6 \%$ : in 1990 it was about $0.2 \%$, by 2015 it rose to $3.2 \%$, and in 2050 it will be about $8 \%$.

Direct gamma spectrometric measurements allow identifying in RA samples of local area only ${ }^{137} \mathrm{Cs},{ }^{241} \mathrm{Am}$ and ${ }^{154} \mathrm{Eu}$. Activity of other nuclides, ${ }^{90} \mathrm{Sr}$ and plutonium

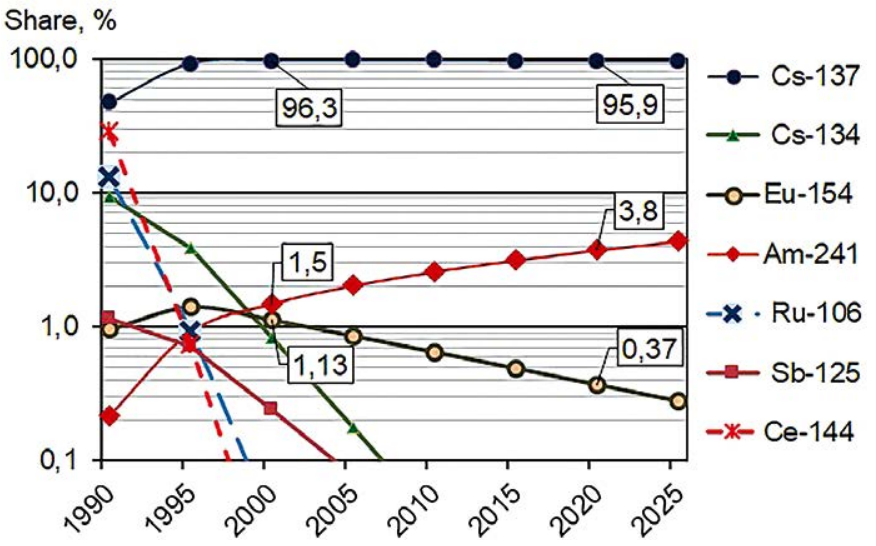

Fig. 2. Relative share (\%) of $\gamma$-emitting nuclides in total $\gamma$-activity RA

isotopes $\left({ }^{238,239,240,241} \mathrm{Pu}\right)$, is determined using the correlation coefficients between the activity values of nuclides averaged over the all reactor core of the 4 th power unit at the moment of accident (the base fuel). The validity of such approach was confirmed by the results of theoretical and special experimental works [1-4].

To estimate operatively ${ }^{90} \mathrm{Sr}$ and plutonium isotopes $\left({ }^{238,239,240,241} \mathrm{Pu}\right)$ activities in aerosols the following correlation ratios with ${ }^{137} \mathrm{Cs}$ and ${ }^{241} \mathrm{Am}$ activities are used:

for ${ }^{90} \mathrm{Sr} A_{\mathrm{Sr}}=K_{\mathrm{SrCs}} \cdot A_{\mathrm{Cs}}$, where $A_{\mathrm{Sr}}-{ }^{90} \mathrm{Sr}$ activity in aerosols, $A_{\mathrm{Cs}}-$ measured ${ }^{137} \mathrm{Cs}$ activities in aerosols, $K_{\text {SrCs }}-$ coefficient of ratio ${ }^{90} \mathrm{Sr}$ to ${ }^{137} \mathrm{Cs}$ activities in the base fuel;

after 2014 for ${ }^{90} \mathrm{Sr} A_{\mathrm{Sr}}=K_{\mathrm{SrAm}} \cdot A_{\mathrm{Am}}$, where $A_{\mathrm{Am}}-$ measured ${ }^{241} \mathrm{Am}$ activities in aerosols, $K_{\mathrm{SrAm}}-$ coefficient of ratio ${ }^{90} \mathrm{Sr}$ to ${ }^{241} \mathrm{Am}$ activities in the base fuel [4];

for plutonium isotopes $A_{\mathrm{Pu}}=K_{\mathrm{PuAm}} \cdot A_{\mathrm{Am}}$, where $A_{\mathrm{Pu}}-{ }^{238,239,240,241} \mathrm{Pu}$ activity in aerosols, $K_{\mathrm{PuAm}}-$ coefficient of ratio plutonium isotope $\left({ }^{238,239,240,241} \mathrm{Pu}\right)$ to ${ }^{241} \mathrm{Am}$ activities in base fuel.

The ratios between ${ }^{137} \mathrm{Cs},{ }^{241} \mathrm{Am}$ and ${ }^{154} \mathrm{Eu}$ in samples of RA indicate that use of the correlation approaches to estimate activities of plutonium isotopes and ${ }^{90} \mathrm{Sr}$ are correct.

The average annual value of coefficients $K_{\mathrm{SrCs}}$ within 2000-2019 are nearly constant and were to about 0,83 . The applied average annual value of coefficients $K_{\mathrm{SrAm}}, K_{\mathrm{PuAm}}$ in 2014, 2016, 2019 are presented in Table 2.

Table 2. The value of ratio coefficients

\begin{tabular}{|c|c|c|c|}
\hline Name of coefficients & 2014 & 2016 & 2019 \\
\hline$K_{\text {SrAm }}$ & 26 & 24 & 21 \\
\hline$K_{\text {Pu241Am }}$ & 10.3 & 9.1 & 7.6 \\
\hline$K_{\text {Pu238-240Am }}$ & 0.77 & 0.75 & 0.72 \\
\hline
\end{tabular}




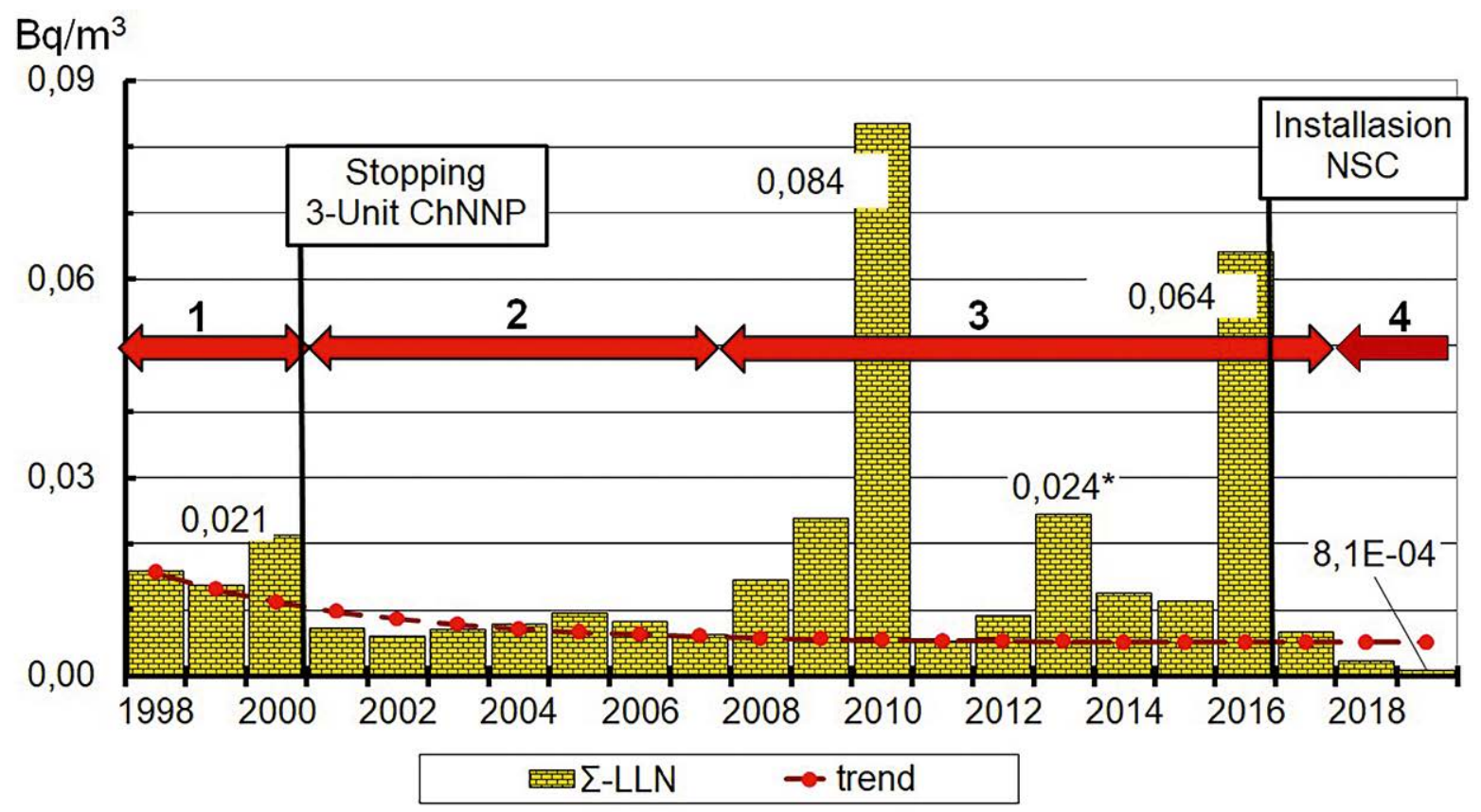

Fig. 3. Dynamics of annual VA of $\sum$-LLN in ground level air of the Shelter object local area

\section{Results and discussion}

Results of RA monitoring in the surface air of local area. The dynamics of the annual average VA of $\Sigma$-LLN in the air from 1998 to 2019 by RA monitoring data is presented in Fig. 3. The trend line on monitoring data to forecast VA of $\Sigma$-LLN in the surface air of local area has been built by equation 1 :

$$
\begin{aligned}
& C_{R R}(t)=(0.014 \pm 0.003) \cdot \exp (-\mathrm{t} /(3.3 \pm 0,6)+ \\
& +(0.005 \pm 0.0009),
\end{aligned}
$$

where $t$ - amount of years from the start of observing.

The regression analysis includes only those years (1998-2004, 2006, 2007, 2011), when intensive ground excavation works were not performed. It was done to provide data homogeneity. As the result, the trend line presents the radiation situation in the surface air only under radioactive releases impact from the SO and regular technological activity.

Herewith average approximation error did not exceed $15 \%$. The greatest deviations from forecast values (ten-fold excess) were registered in periods of earthwork $(2009,2010)$ and the SO structures dismantling $(2016)$.

In general, based on the principle of superposition and independence of aerosol sources, the VA of $\Sigma$-LLN in the local area $C_{\Sigma}(t)$ can be represented as the components sum:

$$
C_{S}(t)=C_{R R}(t)+C_{T A}+C_{A C},
$$

where $C_{T A}$ - the VA of RA caused by technological ac- tivities in the local area; $C_{A C}-$ the VA of RA associated with radioactive releases in abnormal situations or accidents.

Four periods can be determined in the dynamic of annual VA of RA at the transformation stage of the SO into an ecologically safe system.

The first period is determined within 1998-2000 years, when the last power Unit 3 of the ChNPP was operated and the dust suppression system was worked only over the Central Hall of ruined Unit 4 . The average VA of $\Sigma$-LLN over the first period was $17 \mathrm{mBq} / \mathrm{m}^{3}$.

The second period is determined from 2001 to 2007, it includes: the implementation of the stabilization measures of the 4the Unit unstable building structures, the creation and commissioning of modernized dust suppression system over dust clusters around the Central Hall to reduce unorganized RA releases through eakness and holes in the SO. At that time, annual average VA of $\Sigma$-LLN over the second period was $7.4 \mathrm{mBq} / \mathrm{m}^{3}$.

The third period is determined from 2008 to 2017. It was the time of foundation strips construction, mounting the NSC structure and preparing to the NSC commissioning. In 2010, annual VA of RA in local area air reached the highest values of $84 \mathrm{mBq} / \mathrm{m}^{3}$. It was the result of a treatment with radioactive ground during earthworks at foundation strips (see Fig. 1). Maximum $\Sigma$-LLN VA was reached in 2010, and it was equal to $0.51 \mathrm{~Bq} / \mathrm{m}^{3}$. [5] Annual average VA had dropped to $5.3 \mathrm{mBq} / \mathrm{m}^{3}$ in 2011 after earthwork was completed. 
In the beginning of 2013 an incident occurred when a part of the turbine hall roof destroyed and collapsed. The total hole square was estimated to about $600 \mathrm{~m}^{2}$. During the incident were released a huge volume of radioactive dust that sedimented near the SO. At the end of 2013, the old ventilation stack (VT-2) was dismantled. All these events led to an increase of the average annual VA of $\Sigma$-LLN to $24 \mathrm{mBq} / \mathrm{m}^{3}$ in 2013.

The next significant growth of RA VA to $62 \mathrm{mBq} / \mathrm{m}^{3}$ was observed in 2016 . Weekly maximum activity reached $18 \mathrm{mBq} / \mathrm{m}^{3}$ for $\Sigma \alpha$-LLN and $1,400 \mathrm{mBq} / \mathrm{m}^{3}$ for $\Sigma \beta$-LLN. It was during works on dismantling of the SO concrete and metal structures and erection of eastern and western walls of the NSC enclosure perimeter. The average VA of $\Sigma$-LLN over all third period was $25 \mathrm{mBq} / \mathrm{m}^{3}$ [6].

The fourth period started in 2018 after completion of works on the NSC commissioning. Thus, an average annual activity of $\Sigma L L N$ in the surface air dropped to $1.8 \mathrm{mBq} / \mathrm{m}^{3}$. It is about three times less than the forecast value of $5 \mathrm{mBq} / \mathrm{m}^{3}$ and an order below the VA observed before the NSC construction was started. In 2019, an average annual activity of $\Sigma L L N$ decrease more to $9.2 \cdot 10^{-4} \mathrm{mBq} / \mathrm{m}^{3}$. Such difference is associated to the fact that the trend line is considering the share of radioactive release from the SO in RA of the surface air, but after the NSC commissioning, practically, there are no releases.

Ratio nuclides in radioactive aerosols of the local zone. An important characteristic of RA are ratios between radionuclides, since under the conditions of the local area, it indicates a degree of fuel particles transformation and types of carried out technological works. It is connected to the different physicochemical properties of nuclides contained in RA.

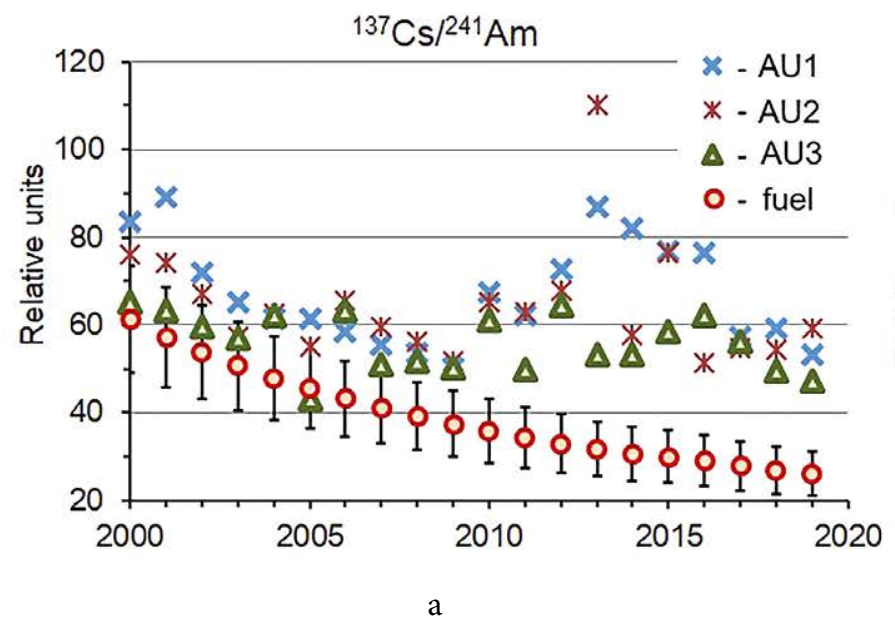

The average annual ratios of ${ }^{137} \mathrm{Cs}$ to ${ }^{241} \mathrm{Am}$ and ${ }^{154} \mathrm{Eu}$ to ${ }^{241} \mathrm{Am}$ activities $\mathrm{s}$ in aerosols at each aspiration unit as well as these nuclides ratios in the basic fuel according to the expert estimations are presented in Fig. 4 [1-3].

Analysis of the data monitoring showed that, firstly, the ${ }^{137} \mathrm{Cs}$ and ${ }^{241} \mathrm{Am}$ ratios observed at AU-3 differs from the ratios at AU-1 and AU-2 and, close enough to expert estimations. It could indicate different origin of radioactive aerosols in the air. Secondly, the trend of decreasing the ${ }^{137} \mathrm{Cs} /{ }^{241} \mathrm{Am}$ in the experimental data within 2000-2009 were correspond to the experts' data trend. Since 2010, deviations between the ratio ${ }^{137} \mathrm{Cs} /{ }^{241} \mathrm{Am}$ in RA of the ground level air and the ratio in the basic fuel had increased and became above $100 \%$.

Obviously, it is due to the fact that in 2010 the intensive excavation work (2009-2010) were completed and a significant volume of radioactive particles which adsorbed ${ }^{137} \mathrm{Cs}$ precipitated on the surface of local area and closer buildings. At the same time, a volume of radioactive releases (fuel particles) from the SO decreased. As a result, it led to the growth in the aerosols share of the ground level air containing ${ }^{137} \mathrm{Cs}$ not associated with fuel particles (free).

In addition, at the end of 2013, VT-2 was dismantled and, then at the site near $3^{\text {rd }}$ Unit of the ChNPP, fragments of VT-2 have been cut over (see Fig. 1). Results of RA monitoring at that time were shown that the ${ }^{137} \mathrm{Cs}$ activity increased more in tenfold. So, it is known, that during hot works (welding, cutting of metal and concrete) a considerable growth of ${ }^{137} \mathrm{Cs}$ activity in aerosols is observed. The maximum of ${ }^{137} \mathrm{Cs}$ and ${ }^{241} \mathrm{Am}$ ratios were fixed on AU-1-440 and on AU-2-1000 from December 9 to 23, 2013. For comparison, the ${ }^{137} \mathrm{Cs}$ and ${ }^{241} \mathrm{Am}$ ratio in the basic fuel at that time was 31 .

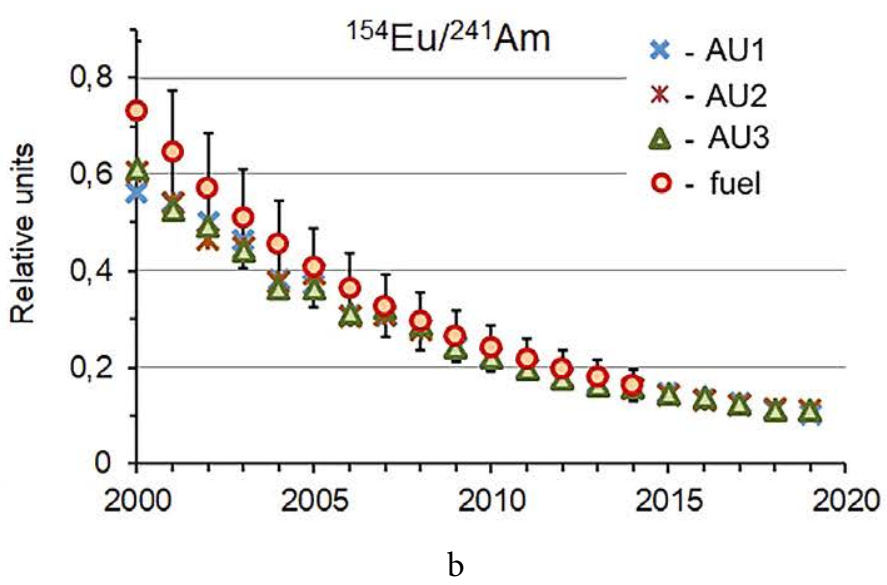

Fig. 4. Average annual ratios of ${ }^{137} \mathrm{Cs}$ and ${ }^{241} \mathrm{Am}(\mathrm{a}),{ }^{154} \mathrm{Eu}$ and ${ }^{241} \mathrm{Am}(\mathrm{b})$ in the surface air at control points AU-1, AU-2, AU-3 within 2000-2019 


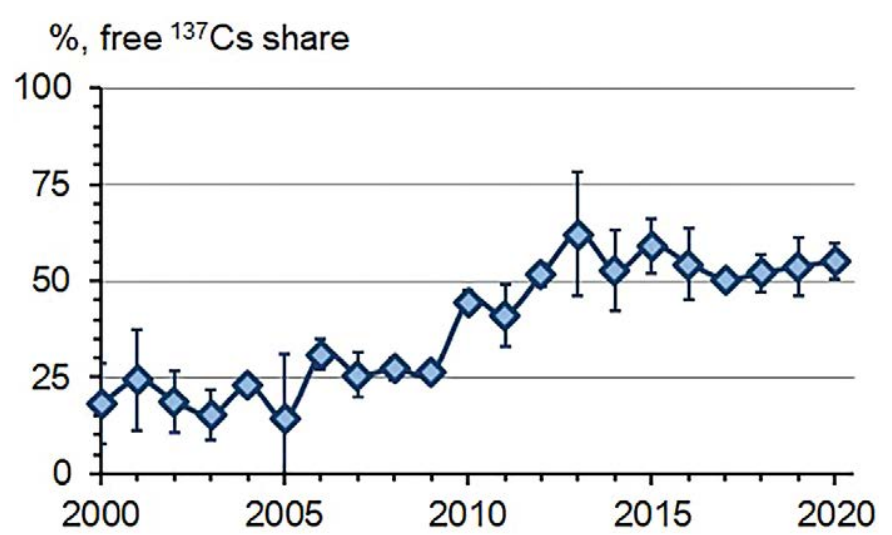

Fig. 5. Dynamic of relative share of ${ }^{137} \mathrm{Cs}$ unassociated with fuel in radioactive aerosols of local area

The ${ }^{241} \mathrm{Am} /{ }^{154} \mathrm{Eu}$ ratios in the RA of local area air and according to expert's estimations are close enough. The average relative deviation of ${ }^{241} \mathrm{Am} /{ }^{154} \mathrm{Eu}$ ratios between them is about $13 \%$ and these differences are insignificant.

The relative share of free ${ }^{137} \mathrm{Cs}$ in the total activity of ${ }^{137} \mathrm{Cs}$ in aerosols using the ${ }^{137} \mathrm{Cs} /{ }^{241} \mathrm{Am}$ and ${ }^{241} \mathrm{Am} /{ }^{154} \mathrm{Eu}$ ratios have been calculated. The results are shown in Fig. 5.

It can be seen that until 2010 the share of a condensation cesium and leached cesium from fuel particles in the total activity of ${ }^{137} \mathrm{Cs}$ did not exceed $30 \%$. Then in 2013 it reached a maximum in $62 \%$ and stabilized within $50-55 \%$ after 2017. Therefore, use of the coefficient $K_{\mathrm{SrCs}}$ for basic fuel after 2017 when calculating the ${ }^{90} \mathrm{Sr}+{ }^{90} \mathrm{Y}$ activity in the RA could overestimated the ${ }^{90} \mathrm{Sr}+{ }^{90} \mathrm{Y}$ value about 1.6 times, and in hot works (cutting, welding), for example as in 2013, it can be increased by more than tenfold.

Hence, the correlation approach application for calculating a share of ${ }^{90} \mathrm{Sr}+{ }^{90} \mathrm{Y}$ in $\Sigma \beta$-LLN by ratio with the ${ }^{241} \mathrm{Am}$ activity is more correct. This significantly reduced errors at estimating a ${ }^{90} \mathrm{Sr}$ activity in aerosols. For confirming this sentence, the annual ratio ${ }^{90} \mathrm{Sr}+{ }^{90} \mathrm{Y}$ to ${ }^{137} \mathrm{Cs}$ in radioactive aerosols of local area within 2017-2019 are presented in Table 3.

From the Table 3 are following, at first, the annual ratios in aerosols about two times lower the in fuel. Second, the maximum values of ratios in RA (2019) can exceeded

Table 3. The values of ratio ${ }^{90} \mathrm{Sr}+{ }^{90} \mathrm{Y}$ to ${ }^{137} \mathrm{Cs}$

\begin{tabular}{|l|c|c|c|c|}
\hline \multicolumn{1}{|c|}{$\begin{array}{c}\text { The ratio } \\
{ }^{90} \mathrm{Sr}+{ }^{90} \mathrm{Y} /{ }^{137} \mathrm{Cs}\end{array}$} & 2016 & 2017 & 2018 & 2019 \\
\hline in fuel & 1.7 & 1.7 & 1.7 & 1.7 \\
\hline \multirow{2}{*}{$\begin{array}{l}\text { in aerosols: } \\
\text { mean } \\
\begin{array}{l}\text { min } \\
\max \end{array}\end{array}$} & 0.87 & 0.89 & 0.91 & 0.95 \\
\cline { 2 - 5 } & 0.062 & 0.33 & 0.30 & 0.32 \\
\cline { 2 - 5 } & 1.9 & 1.5 & 1.6 & 2.9 \\
\hline
\end{tabular}

than the ratio in fuel. It means that in the local area air could present RA was generated by lava-like fuel-containing materials (LFCM). A depletion by cesium is inherent to some types of LFCM inside the SO, for example, located in premises 012/7 [7].

\section{Conclusion}

1. The commissioning of the NSC "Arch" in 2018 promoted tenfold decrease of RA activity in aerosols near the SO, as compared to the end of 1990s. The annual average VA of $\Sigma$-LLN in 2019 dropped to $0.81 \mathrm{mBq} / \mathrm{m}^{3}$. On top of that, the VA of aerosols will continue to drop according to ordering of adjacent territory, further accumulation of radioactive particles by the environmental objects, radioactive decay and, the main, absence of radioactive releases from the SO.

2. Major decline in aerosol situation of the SO local area air, when the VA of RA were growing by tenfold as compared to the beginning of 2000s, is linked to radioactive dust resuspension from the radioactive contaminated surfaces:

3. at performed earthwork to build foundation strips of the NSC in 2010, when maximum annual average VA of $\Sigma$-LLN equal to $0.08 \mathrm{~Bq} / \mathrm{m}^{3}$ was registered;

4. during works on dismantling of the SO concrete and metal structures in 2016, annual average VA of $\Sigma$-LLN was $62 \mathrm{mBq} / \mathrm{m}^{3}$ and weekly maximum activity of $\Sigma \alpha$-LLN reached to $18 \mathrm{mBq} / \mathrm{m}^{3}$ and $\Sigma \beta-L L N-1400 \mathrm{mBq} / \mathrm{m}^{3}$.

5. The decommissioning of the $3^{\text {rd }}$ power Unit and the stabilization measures implementation have led to reduction of the VA of RA about two times.

6. To improve the estimation accuracy of the fraction of ${ }^{90} \mathrm{Sr}+{ }^{90} \mathrm{Y}$ in the $\Sigma \beta$-LLN of the surface air of the local area, it is necessary to use the ${ }^{90} \mathrm{Sr}+{ }^{90} \mathrm{Y}$ and ${ }^{241} \mathrm{Am}$ ratio in the base fuel. In this case, the coefficient $K_{S r A m}$ should be calculated for the moment of $\gamma$-spectrometric measurements.

\section{References}

1. Begichev C. H., Borovoi A. A., Burlakov E. B., Gavrilov S. L., et al. (1990). Fuel of ChNPP Unit 4 (brief reference-book). Preproject No. 5268/3. Moscow: I. V. Kurchatov IAE,. (in Russ.)

2. Borovoi A. A., Dovbenko A. A., Smolyakina M. V., Stroganov A. A. (1991) Definition of fuel nuclear-physical properties of ChNPP Unit 4. Inv. No52/11-20. Moscow: IBRAE USSR AS. (in Russ.)

3. Loshchilov N. A., Kashparov V. A., Yudin E. B., Protsak V. P. (1992). [Fractionation of radionuclides in Cher- 
nobyl fuel hot particles]. Radiochemistry, vol. 34, no. 5, pp. 125-134. (in Russ.)

4. Kalynovsky A. K., Odintsov O. O., Chikur L. B. [Fractionation of radionuclides in aerosols of the the Shelter object local area by results of radiochemical separation]. Problems of Nuclear Power Plants' Safety and of Chornobyl, vol. 26, pp. 90-96. (in Russ.)

5. Kalynovsky A. K., Krasnov V. A., Ogorodnikov B. I. (2011). [Radioactive aerosols in the local area of the Shelter object during 2009-2010]. Problems of Nuclear Power Plants' Safety and of Chornobyl, vol. 17, pp. 106-112. (in Russ.)

6. Shynkarenko V. K., Kashpur V. O., Skorjak G. G., Kalynovsky A. K. (2016). [Assessment of aerosol radiation situation on industrial site of the ChNPP during work on building of the New Safe Confinement]. Problems of Nuclear Power Plants' Safety and of Chornobyl, vol. 27, pp. 58-66. (in Russ.)

7. Ogorodnikov B. I., Khan V. Y., Kovalchuk V. P. (2013). [Aerosols as evidences of destruction of lava-like fuel containing materials in the "Ukryttya" Object]. Problems of Nuclear Power Plants and of Chornobyl, vol. 20, pp. 94-106. (in Russ.)

\section{О. К. Калиновський, В. О. Краснов, О. В. Філіппов}

Інститут проблем безпеки АЕС НАН України, вул.

Кірова, 36а, Чорнобиль, 07270, Україна

\section{Моніторинг радіоактивних аерозолів у приземному шарі повітря поблизу об'єкта “Укритття" в період 1998-2019 pp.}

У статті наведено результати багаторічного моніторингу радіоактивних аерозолів (РА) у приземному шарі повітря (1998-2019 рр.) в умовах проведен- ня робіт поблизу об'єкта “Укриття” (локальна зона) під час виконання проектів зі створенні нового безпечного конфайнмента (НБК) “Арка”. До складу довгоіснуючих нуклідів (ДІН) у повітрі локальної місцевості для оцінки радіаційної безпеки персоналу включали нукліди: $\Sigma \alpha$-ДІН $\left({ }^{238,239,} 240 \mathrm{Pu},{ }^{241} \mathrm{Am}\right)$ і $\Sigma \beta$-ДІН $\left({ }^{137} \mathrm{Cs}\right.$, $\left.{ }^{90} \mathrm{Sr}+{ }^{90} \mathrm{Y},{ }^{241} \mathrm{Pu}\right)$.

Середньорічна об'ємна активність $\Sigma$-ДІН становила близько 17 мБк/м³ у кінці 90-х рр. у повітрі локальної зони. Основне погіршення аерозольної ситуації поблизу об'єкта “Укриття”, коли активність РА збільшилася в 10 разів у порівнянні з початком 2000-х рр., пов'язане з ресуспендуванням радіоактивного пилу під час технологічних робіт. Одним фактором стали земляні роботи під час будівництва фундаментних смуг НБК у 2010 р. У цей період середньорічна об’ємна активність $\Sigma$-ДІН становила 80 мБк/ $\mathrm{M}^{3}$, а щотижнева максимальна актив-

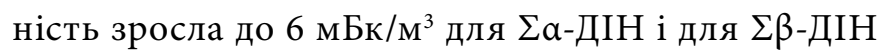

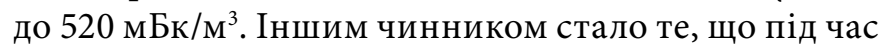
демонтажу бетонних і металевих конструкцій об’єкта "Укриття" в 2016 р. середньорічна активність $\Sigma$-ДІН склала 62 мБк/м ${ }^{3}$, а тижнева максимальна активність досягла $\Sigma \alpha$-ДІН -18 мБк/м ${ }^{3}$ і $\Sigma \beta$-ДІН -

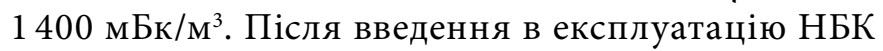
в 2019 р. об’ємна активність $\Sigma$-ДІН у повітрі знизилася до $0,8 \mathrm{мБк} / \mathrm{M}^{3}$.

Показано, що після 2010 р. в РА приземного шару повітря відбувається зростання активності ${ }^{137} \mathrm{Cs}$, не пов'язаного з паливними частинками, середня відносна частка якого на початку 2000 рр. становила близько $20 \%$, у 2013 р. досягла $62 \%$, а після 2017 р. лежить у межах 50-55\%.

Ключові слова: моніторинг радіоактивних аерозолів, довгоіснуючі нукліди, об’ємна активність, новий безпечний конфайнмент. 